\title{
Redesain Turbin 175 KW Untuk Pembangkit Listrik Tenaga Mikrohidro (PLTMH) Desa Mekar Sari Buleleng Bali
}

\author{
Dewa Putu Ari Laksana ${ }^{1}$, Ida Ayu Dwi Giriantari ${ }^{2}$, I Nyoman Satya Kumara ${ }^{3}$ \\ [Submission: 09-11-2020, Accepted: 30-11-2020]
}

The Mekar Sari Buleleng Micro Hydro Power Plant (MHP) has been around since 1980. MHP capacity of 10 $k W$ is experiencing various problems that lead to optimal operation. One of the proposed improvements is a decadesold turbine redesign. The redesign of the turbine resulted in a crossflow turbine with a capacity of $185 \mathrm{~kW}$. The performance of the turbine was validated using Computational Fluid Dynamics (CFD) software with a simulation of the average turbine power output of $175 \mathrm{~kW}$. One of the improved features used in this turbine design is the nozzle design so that the turbine's output power can be maximized.

Keywords: renewable energy, MHP, micro hydro, crossflow turbine, nozzle, $C F D$

Pembangkit Listrik Tenaga Mikro Hidro (PLTMH) Mekar Sari Buleleng sudah ada sejak tahun 1980. PLTMH berkapasitas $10 \mathrm{~kW}$ ini mengalami berbagai permasalahan yang mengakibatkan operasi tidak optimal. Salah satu perbaikan yang diusulkan adalah redesain turbin yang sudah berumur puluhan tahun. Desain ulang turbin menghasilkan turbin crossflow dengan kapasitas $185 \mathrm{~kW}$. Unjuk kerja turbin divalidasi dengan perangkat lunak Computational Fluid Dynamics (CFD) dengan simulasi keluaran daya rata-rata turbin adalah $175 \mathrm{~kW}$. Salah satu fitur perbaikan yang digunakan pada desain turbin ini adalah desain dari nosel sehingga daya keluaran turbin dapat dibuat maksimal.

Kata kunci : Energi terbarukan, PLTMH, mikrohidro, turbin crossflow, nosel,CFD

\section{PENDAHULUAN}

Bali merupakan salah satu provinsi yang ada di Indonesia yang memiliki hampir empat juta penduduk dan luas daratan 5.600 kilometer persegi. Sekarang ini rasio elektrifikasi Bali sudah mencapai 100\%. Sistem kelistrikan

\footnotetext{
${ }^{1}$ Mahasiswa,Program Studi Teknik Elektro Fakultas Teknik Universitas Udayana, Jalan Bhuana Raya no 103,Denpasar 80117. Indonesia (telp:081939682960;email:agoesstarchild@gmail.com)

${ }^{2,3}$ Dosen,Program Studi Teknik Elektro Fakultas Teknik Universitas Udayana, Jln. Jalan Kampus Bukit Jimbaran 80361 INDONESIA (telp: 0361-703315; fax: 0361-4321; e-mail: 22dayu.giriantari@unud.ac.id, ${ }^{3}$ satya.kumara@unud.ac.id)
}

Dewa Putu Ari Laksana : Redesain Turbin 175 KW Untuk ...
Bali didukung oleh pembangkit dengan total daya 1274 MW tetapi dengan beban puncak sudah pada 980 MW. Bali tidak memiliki sumber daya konvensional sehingga semua bahan bakar berbasis fosil. Untungnya, Bali memiliki berbagai sumber daya terbarukan yang dapat dimanfaatkan untuk pembangkit listrik. Sumber daya terbarukan yang tersedia di pulau ini adalah mikrohidro, angin, fotovoltaik, biomassa, dan juga panas bumi [1]. Pembangkit listrik tenaga mikrohidro di Bali akan terus dikembangkan dengan dikeluarkannya Pergub Bali 45/2019 energi bersih.

Bali memiliki potensi PLTMH yang besar hal ini dapat diketahui dari beberapa rencana pembangunan minihidro di Bali ke depan dengan total daya $30 \mathrm{MW}$ [2]. Pemanfaatan PLTMH di Bali sudah dilakukan sejak dulu dan mencapai puncaknya disekitar tahun 80-an dimana terdapat ratusan PLTMH tersebar diseluruh Bali. Namun dengan adanya program listrik masuk desa maka hampir semua PLTMH tersebut tidak lagi beroperasi sehingga berangsur-angsur rusak. Salah satu faktor yang menyebabkan PLTMH tidak beroperasi lagi yaitu kurangnya partisipasi masyarakat pada saat pembangunan PLTMH sehingga menimbulkan adanya ketidakpedulian dan rendahnya rasa memiliki pada masyarakat dalam menjaga keberadaan PLTMH [3]. Berbagai penelitian tentang kajian PLTMH khususnya di daerah Buleleng sudah dilakukan seperti penelitian tentang kajian pembangkit PLTMH Tiying Tali [4]. Sekarang ini, salah satu PLTMH yang beroperasi di Bali adalah PLTMH Jatiluwih yang dibangun dengan kerjasama Toyama Jepang, Pemerintah Kabupatan Tabanan, dan Universitas Udayana [5].

Salah satu pembangkit listrik tenaga mikrohidro yang ada di Desa Panji adalah PLTMH Mekar Sari merupakan pembangkit listrik tenaga mikrohidro yang sudah ada sejak tahun 1980 yang beroperasi hingga sekarang. PLTMH ini memiliki kapasitas generator $10 \mathrm{~kW}$. Namun, PLTMH ini mengalami banyak permasalahan diantaranya pada proses pembangunan PLTMH tidak diperhitungkan head net dan jenis turbin yang akan digunakan. Selain itu, setelah PLTMH beroperasi tidak dilakukan pemeliharaan secara berkala. Kondisi turbin air saat ini sudah berkarat dan banyak yang berlubang. Sudu-sudu pada turbin ada lepas dan tidak di pasang oleh pihak pengelola. Permasalahan tersebut mengakibatkan penurunan daya keluaran turbin.

Untuk mengatasi permasalahan di atas maka dalam penelitian ini akan dilakukan perancangan ulang desain PLTMH untuk memanfaatkan aliran air pada Tukad Pasut secara optimal. Artikel ini membahas redesain turbin p-ISSN:1693 - 2951; e-ISSN: 2503-2372 
PLTMH Mekar Sari berdasarkan data potensi di lokasi. Hasil desain turbin ini kemudian divalidasi dengan perangkat lunak Computational Fluid Dynamics (CFD).

\section{KAJIAN PUSTAKA}

A. Pembangkit Listrik Tenaga Mikrohidro

Pembangkit Listrik Tenaga Mikrohidro (PLTMH) adalah suatu pembangkit listrik skala kecil yang menggunakan tenaga air sebagai tenaga penggeraknya seperti saluran irigasi, sungai atau air terjun alam dengan cara memanfaatkan tinggi terjunan (head) dan jumlah debit air. Pada dasarnya, mikrohidro memanfaatkan energi potensial jatuhan air (head). Semakin tinggi jatuhan air maka semakin besar energi potensial air yang dapat diubah menjadi energi listrik [6]. Berdasarkan besar daya keluarannya, PLN mengklasifikasikan pembangkit listrik tenaga air menjadi 3 macam, yaitu: pembangkit listrik tenaga mikrohidro (PLTMH), pembangkit listrik tenaga minihidro (PLTM) dan pembangkit listrik tenaga air (PLTA). PLTMH memiliki daya output kurang dari 100 $\mathrm{kW}$, PLTM memiliki daya output 100-1000 kW dan PLTA memiliki daya output lebih dari $1000 \mathrm{~kW}$ [7].

Sebagai pedoman untuk mengetahui daya yang dapat dihasilkan pada studi kelayakan pembangunan PLTMH, secara umum dapat dipakai pedoman rumus persamaan atau diagram sebagai berikut [8].

$$
p_{\text {hydro }}=g \times H_{n} \times Q \text {. }
$$

Maka daya turbin dapat dihitung menggunakan persamaan [9]

$$
P_{t}=\rho \times Q \times H_{n} \times \mathrm{g} \times \eta
$$

Dimana :

$$
\begin{array}{ll}
\mathrm{P}_{\text {hydro }} & =\text { Daya potensi air }(\mathrm{kW}) \\
\mathrm{P}_{\mathrm{t}} & =\text { Daya turbin }(\text { Watt }) \\
\mathrm{Q} & =\text { Debit air }\left(\mathrm{m}^{3} / \mathrm{s}\right) \\
\rho & =\text { Massa jenis air }\left(1000 \mathrm{~kg} / \mathrm{m}^{3}\right) \\
\mathrm{g} & =\text { Gaya gravitasi }\left(\mathrm{m} / \mathrm{s}^{2}\right) \\
\mathrm{H}_{\mathrm{n}} & =\text { Head net }(\mathrm{m}) \\
\eta_{\text {efisiensi turbin }} & =\text { efisiensi turbin }(0,895)
\end{array}
$$

\section{B. Turbin}

Turbin air adalah turbin dengan media kerja air. Secara umum, turbin adalah alat mekanik yang terdiri dări poros dan sudu-sudu. Sudu tetap atau stationary blade, tidak ikut berputar bersama poros, berfungsi mengarahkan aliran fluida. Sedangkan sudu putar atau rotary blade, mengubah arah dan kecepatan aliran fluida sehingga timbul gaya yang memutar poros. Air biasanya dianggap sebagai fluida yang tak kompresibel, yaitu fluida yang secara virtual massa jenisnya tidak berubah dengan tekanan. Pemilihan jenis turbin dapat ditentukan berdasarkan kelebihan dan kekurangan dari jenis-jenis turbin, khususnya untuk suatu desain yang sangat spesifik. Faktor tinggi jatuhan air efektif (Net Head) dan debit yang akan dimanfaatkan untuk operasi turbin merupakan faktor utama yang mempengaruhi pemilihan jenis turbin [9]. Berdasarkan tinggi jatuhan air efektif dan debit air yang akan dimanfaatkan untuk pembangkit listrik, maka dapat ditentukan jenis turbin yang sesuai dengan faktor tersebut menggunakan grafik efisiensi turbin air.

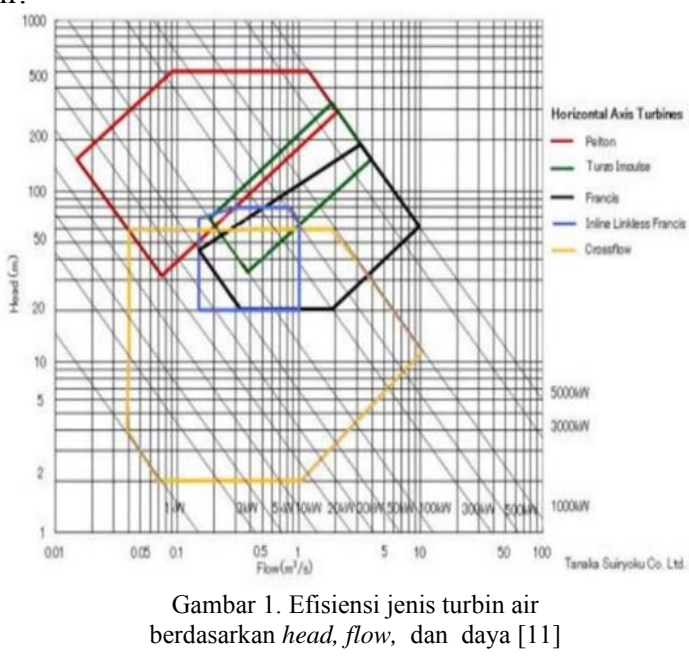

C. Kecepatan Spesifik $\left(n_{s}\right)$

Kecepatan spesifik dari suatu turbin ialah kecepatan putaran runner yang dapat dihasilkan daya efektif untuk setiap tingginya atau dengan rumus dapat ditulis [12].

$$
\begin{aligned}
& N_{s}=N \frac{\sqrt{P_{t}}}{H_{n}^{1,25}} \ldots \ldots \ldots . . \\
& N=513,25 \frac{H_{n}^{0,745}}{\sqrt{P_{t}}} \ldots .
\end{aligned}
$$

Dimana:

$\mathrm{N}_{\mathrm{s}} \quad=$ Kecepatan spesifik turbin (rpm)

$\mathrm{N} \quad=$ Kecepatan Putaran turbin (rpm)

$\mathrm{P}_{\mathrm{t}} \quad$ = Daya turbin (watt)

$\mathrm{H}_{\mathrm{n}} \quad=$ head net $(\mathrm{m})$

Untuk mendapatkan $\mathrm{H}_{\mathrm{n}}$ digunakan persamaan [11].

$$
H_{n}=H_{g}-H_{t l}
$$

Dimana

$\mathrm{H}_{\mathrm{n}} \quad=$ Head net $(\mathrm{m})$

$\mathrm{H}_{\mathrm{g}} \quad=$ Head gross, merupakan jarak vertikal antara permukaan air dari intake menuju turbin $(\mathrm{m})$.

$\mathrm{H}_{\mathrm{tl}} \quad=$ Head total losses, merupakan jumlah losses pada open channel, trash back, intake, penstock, dan gate or value. Biasanya $6 \%$ dari Head gross (m).

\section{Perencanaan Dimensi Turbin PLTMH \\ Perancangan dimensi Turbin}

PLTMH menggunakan persamaan sebagai berikut.

1) Diameter luar runner $\left(D_{o}\right)$ :

$$
D_{o}=40 \frac{\sqrt{H_{n}}}{N} \text {. }
$$

Dimana :

$\begin{array}{ll}\mathrm{D}_{\mathrm{o}} & =\text { Diameter luar runner }(\mathrm{m}) \\ \mathrm{N} & =\text { Kecepatan Putaran turbin }(\mathrm{rpm}) \\ \mathrm{H}_{\mathrm{n}} & =\text { Head net }(\mathrm{m})\end{array}$ 
2) Diameter dalam runner $\left(D_{i}\right)$ :

Perhitungan diameter dalam runner menggunakan persamaan [13]

$$
D_{i}=2 / 3 \times D_{o}
$$

Dimana :

$\mathrm{D}_{\mathrm{i}} \quad=$ Diameter dalam runner $(\mathrm{m})$

$\mathrm{D}_{\mathrm{o}} \quad=$ Diameter luar runner $(\mathrm{m})$

3) Jarak Antar Sudu Pada Turbin Air $\left(s_{1}, t\right)$ : Perhitungan diameter dalam runner menggunakan persamaan [14]

$s_{1}=k \times D_{0}$

$t=\frac{s_{1}}{\sin \beta_{1}}$.

Dimana :

$\mathrm{s}_{1}=$ Ketebalan sudu $(\mathrm{m})$

$\mathrm{k}=$ Konstanta $(0,0087)$

$\mathrm{D}_{\mathrm{o}}=$ Diameter luar runner $(\mathrm{m})$

$\mathrm{t}=$ Jarak antar sudu pada turbin air $(\mathrm{m})$

$\beta_{1}=$ Sudut kecepatan air masuk bagian luar runner

4) Lebar Sudu (a):

$a=0,17 \times D_{o}$

Dimana

$\mathrm{D}_{\mathrm{o}}=$ Diameter luar runner $(\mathrm{m})$

a $=$ Lebar sudu $(\mathrm{m})$

5) Jumlah Sudu Pada Turbin Air :

Perhitungan jumlah sudu menggunakan persamaan [15]

$n=\frac{\pi \times D_{o}}{t}$

Dimana

$\mathrm{n}=$ Jumlah sudu pada turbin air

$\pi=3,14$

$\mathrm{D}_{\mathrm{o}}=$ Diameter luar runner $(\mathrm{m})$

$\mathrm{t}=$ Jarak antar sudu pada turbin air (m)

6) Panjang sudu (L) :

$$
L=\frac{Q \times N}{50 \times H_{n}}
$$

Dimana :

$\mathrm{L}=$ Panjang sudu (m)

$\mathrm{N}=$ Kecepatan Putaran turbin (rpm)

$\mathrm{H}_{\mathrm{n}}=$ Head net $(\mathrm{m})$

$\mathrm{Q}=$ Debit air $\left(\mathrm{m}^{3} / \mathrm{s}\right)$

7) Radius blade curvature $\left(\mathrm{r}_{\mathrm{c}}\right)$

Jari-jari kelengkungan sudu $\left(\mathrm{r}_{\mathrm{c}}\right)$ dihitung dengan Persamaan sebagai berikut [16].

$$
\begin{aligned}
& r_{c}=0,163 \times D_{o} \\
& \text { Dimana } \\
& \text { Do }=\text { Diameter luar runner }(\mathrm{m}) \\
& \mathrm{r}_{\mathrm{c}}=\text { Jari-jari kelengkungan sudu }(\mathrm{m})
\end{aligned}
$$

Dewa Putu Ari Laksana : Redesain Turbin 175 KW Untuk ...

\section{E. Momen Gaya Rotasi}

Energi utama dari turbin crossflow adalah energi potensial pada aliran air yang mengenai sudu turbin. Gerakan rotasi dari runner dikarenakan adanya torsi yang timbul dari interaksi antara aliran air dengan sudu dari turbin. Hal ini menjadikan turbin crossflow sebagai penggerak mula dari generator agar dapat menghasilkan listrik. Torsi adalah gaya pada gerak translasi menunjukkan kemampuan sebuah gaya untuk membuat benda melakukan gerak rotasi/berputar. Sebuah benda akan berotasi bila dikenai torsi. Satuan yang sering digunakan adala Newton meter $(\mathrm{Nm})$. Torsi pada motor listrik dapat diperoleh dari hasil bagi antara daya keluaran (Watt) dengan banyaknya putaran per detik (rpm) [17].

Untuk dapat menentukan besar torsi yang dihasilkan dapat menggunakan persamaan berikut [18].

$$
\mathrm{T}=\frac{P_{t}}{2 \pi \frac{N}{60}}
$$

$$
\begin{aligned}
& \text { Keterangan : } \\
& \mathrm{T} \quad=\text { Torsi }(\mathrm{Nm}) \\
& \mathrm{Pt} \quad=\text { Daya turbin (Watt) } \\
& \mathrm{N} \quad=\text { Putaran mesin (rpm) }
\end{aligned}
$$

\section{Metodologi Penelitian}

Langkah-langkah penelitian ini disajikan secara skematik pada Gambar 2 sebagai berikut.

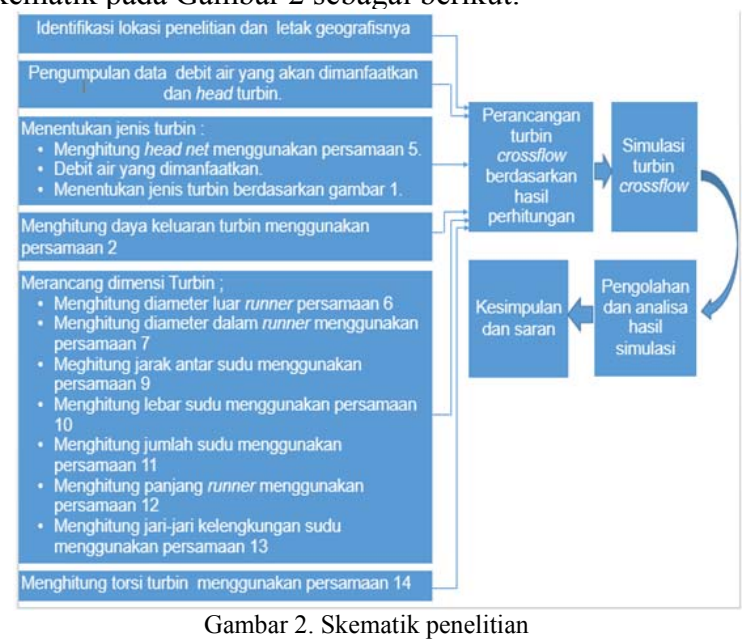

Penelitian di awali dengan indentifikasi lokasi penelitian untuk mengetahui lokasi dari PLTMH dan kondisi terkini dari PLTMH Mekar Sari serta letak geografisnya menggunakan Google Earth.

Langkah selanjutnya adalah pengumpulan debit air yang dimanfaatkan yang diketahui $1,32 \mathrm{~m}^{3} /$ detik. Dari hasil observasi terakhir diperoleh bahwa kondisi debit tidak banyak berubah. Selain itu, perkiraan head PLTMH dilakukan dengan menggunakan Google Earth untuk mengetahui head grossnya. Dengan diketahui head gross

$$
\text { p-ISSN:1693 - 2951; e-ISSN: 2503-2372 }
$$


maka head net pada PLTMH dapat dihitung menggunakan Persamaan 5. Dengan data debit air yang dimanfaatkan dan head net maka jenis turbin yang digunakan pada PLTMH dapat ditentukan melalui Gambar 1. Selain itu, daya keluaran dapat dihitung menggunakan Persamaan 2. Dengan diketahui daya keluaran turbin maka kecepatan putaran turbin dapat dihitung menggunakan Persamaan 4.

Dengan diketahuinya daya keluaran turbin maka dimensi turbin dapat dihitung menggunakan Persamaan 6 hingga 13. Kemudian torsi turbin dapat dihitung menggunakan Persamaan 14.

Simulasi turbin menggunakan aplikasi computational fluid dynamics (CFD) yang masukan datanya debit air dan putaran turbin untuk mendapatkan keluaran torsi dari turbin.

Berdasarkan data yang telah dikumpulkan dan hasil simulasi kemudian dikelola dan analisa untuk mengetahui daya keluaran turbin.

\section{HASIL DAN PEMBAHASAN}

Desa Panji merupakan salah satu dari 14 desa yang ada di Kecamatan Sukasada Kabupaten Buleleng yang memiliki luas wilayah $10,61 \mathrm{~km}^{2}$ dengan jumlah penduduk 11577 jiwa [19]. Mayoritas penduduk di Desa Panji bekerja sebagai petani baik lahan basah maupun kering.

Listrik yang ada di Desa Panji di pasok melalui penyulang Panji, namun untuk daerah selatan Desa Panji belum semua teraliri listrik dikarenakan akses jalan yang belum memadai. Jarak terdekat untuk mencapai jaringan listrik PLN adalah $1 \mathrm{~km}$. Lokasi Desa Panji dapat dilihat pada Gambar 3.

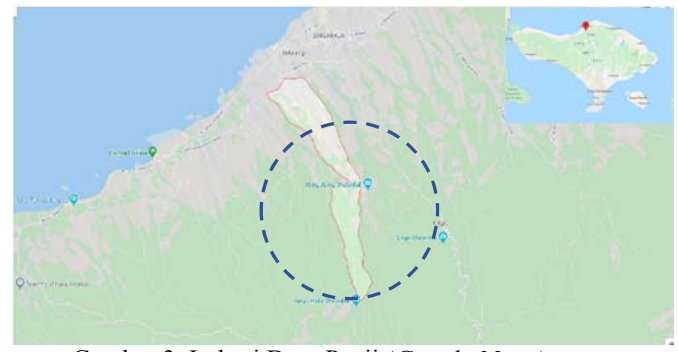

Gambar 3. Lokasi Desa Panji (Google Maps)

PLTMH Mekar Sari adalah sebuah pembangkit yang dibangun pada tahun 1980 dan digunakan sebagai sumber tenaga listrik oleh masyarakat di Desa Panji. Namun sejak tahun 2019, PLTMH ini sudah tidak beroperasi lagi karena sudah tua dan banyak komponennya yang rusak. Sungai yang dimanfaatkan untuk PLTMH adalah sungai atau Tukad Pasut. Gambar 4 menunjukkan kondisi sungai Pasut dan turbin PLTMH Mekar Sari.
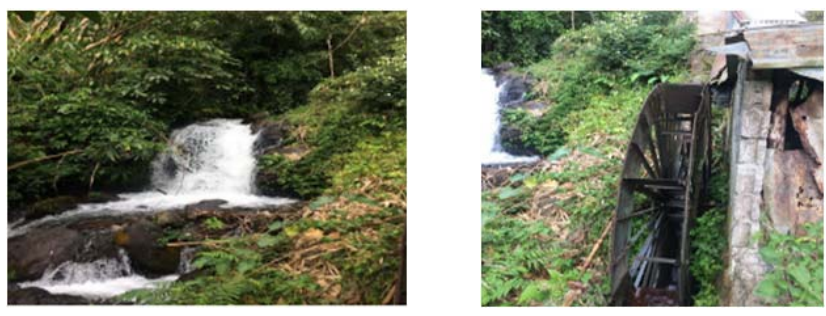

(a) Sungai Pasut

(b) Turbin lama
Gambar 4. Sungai dan Turbin PLTMH Mekar Sari

PLTMH Mekar Sari terdiri dari bak penenang, governor, penstok, turbin air, pully, generator, instalasi listrik sederhana, dan saluran pembuangan. Untuk lebih jelas bisa dilihat pada Gambar 5.

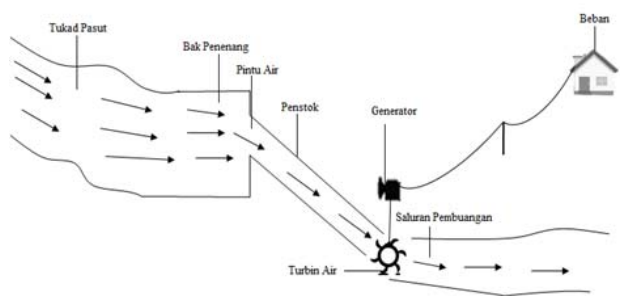

Gambar 5. Skematik PLTMH Mekar Sari

Kondisi komponen PLTMH Mekar Sari kebanyakan sudah tua dan beberapa sudah ada yang rusak. Misalnya turbin, ada beberapa sudu turbin yang sudah lepas namun tidak dipasang oleh pihak pengelola. Selain itu, pada PLTMH Mekar Sari tidak memiliki nosel sehingga tekanan dan kecepatan air yang menembak turbin tidak optimal. Saat ini PLTMH Mekar Sari sudah tidak bisa beroperasi.

Redesain PLTMH yang ada di Banjar Dinas Mekar Sari, Desa Panji memanfaatkan aliran sungai Tukad Pasut yang yang memiliki debit terkecil $1.32 \mathrm{~m}^{3} /$ detik. Head net yang didapatkan adalah $16 \mathrm{~m}$ dengan panjang penstock $54,02 \mathrm{~m}$. Turbin yang akan digunakan adalah turbin crossflow. Generator yang di gunakan adalah mesin berkapasitas $168 \mathrm{~kW}$. Power House yang digunakan adalah yang power house yang sudah ada sebelumnya. Perancangan turbin secara lengkap akan dijelaskan di bawah ini.

\section{A. Pemilihan Jenis Turbin}

Pemilihan jenis turbin di pengaruhi oleh tinggi jatuhan air (head net) dan debit air yang di manfaatkan. Perhitungan head net menggunakan persamaan 5 sebagai berikut.

$$
\begin{aligned}
& H_{\text {gross }}=17 \mathrm{~m} \\
& H_{\text {net }}=H_{\text {gross }}-h_{\text {friction }} \\
& H_{\text {net }}=17-1,039 \\
& H_{\text {net }}=15,961 \mathrm{~m} \text { atau } 16 \mathrm{~m}
\end{aligned}
$$

Data debit aliran yang dimanfaarkan adalah 1,32 $\mathrm{m}^{3} /$ detik . Berdasarkan data debit air dan head net maka dapat ditarik garis pada grafik efisiensi jenis turbin air berdasarkan head, flow, dan daya sebagai berikut.

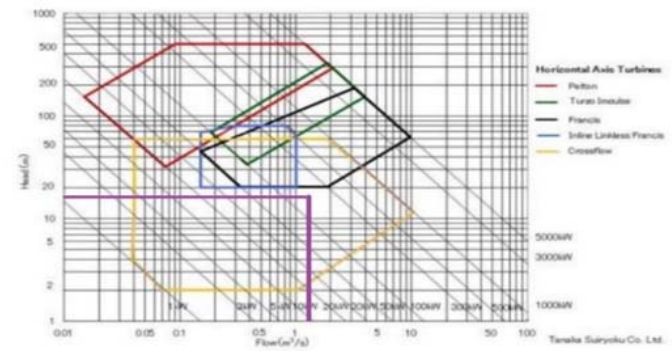

Gambar 6. Karakteristik turbin [11] 
Gambar 6 adalah Gambar jenis turbin yang akan digunakan pada PLTMH. Garis berwarna ungu merupakan garis pertemuan antara debit air yang digunakan dan tinggi jatuhan air yang telah dihitung, sehingga berdasarkan grafik diatas jenis turbin yang akan digunakan pada PLTMH adalah turbin crossflow.

SW-420 sebagai sensor getar. Sensor arus digunakan untuk membaca berapa nilai arus yang ada pada kompresor dan sensor getar akan mendeteksi getaran yang ada pada kompresor namun getaran ini hanya sebagai indikator apakah kompresor hidup atau mati. Kompresor yang memiliki gejala rusak biasanya terdapat nilai arus yang tidak sesuai dengan standar operasi yang ada pada kompresor.

B. Daya Keluaran Turbin $\left(P_{t}\right)$

Daya keluaran turbin dihitung menggunakan Persamaan 2 sebagai berikut.

$$
\begin{aligned}
\left(\mathrm{P}_{\mathrm{t}}\right) & =\rho \times Q \times H_{n} \times \mathrm{g} \times \eta \\
& =1000 \mathrm{~kg} / \mathrm{m}^{3} \times 1,32 \mathrm{~m}^{3} / \text { detik } \times 16 \mathrm{~m} \times 9,81 \\
& \mathrm{~m} / \mathrm{s}^{2} \times 0,895 \\
& =185.432,544 \text { watt } \\
& =185 \mathrm{~kW}
\end{aligned}
$$
$185 \mathrm{~kW}$.

Maka daya keluaran turbin yang didapatkan adalah

\section{C. $\quad$ Kecepatan Turbin $(N)$}

Kecepatan turbin dapat di hitung menggunakan Persamaan 4.

$$
\begin{aligned}
N & =513,25 \frac{H_{n}^{0,745}}{\sqrt{P_{t}}} \\
& =513,25 \frac{16^{0,745}}{\sqrt{185 \mathrm{~kW}}} \\
& =513,25 \times 0,58 \\
& =298 \mathrm{rpm}
\end{aligned}
$$

\section{Perhitungan Dimensi Turbin Crossflow}

Perhitungan dimensi turbin crossflow meliputi perhitungkan sebagai berikut.

1) Menghitung Diameter Luar Runner :

Diameter luar runner dihitung menggunakan Persamaan 6 sebagai berikut.

$$
\begin{aligned}
\mathrm{D}_{0} & =40 \frac{\sqrt{H_{n}}}{N} \\
& =40 \frac{16^{0,5}}{298} \\
& =40 \times 0,013 \\
& =0,54 \mathrm{~m} \text { atau } 54 \mathrm{~cm}
\end{aligned}
$$

2) Menghitung Diameter Dalam Runner:

Diameter luar runner dihitung menggunakan Persamaan 7 sebagai berikut.

$$
\begin{aligned}
D_{i} & =2 / 3 \times D_{o} \\
& =\frac{2}{3} \times 54
\end{aligned}
$$

Dewa Putu Ari Laksana : Redesain Turbin 175 KW Untuk ...

$$
=36 \mathrm{~cm}
$$

3) Menghitung Jarak Antar Sudu :

Jarak antar sudu dapat dihitung dengan mengetahui sudut kecepatan air masuk bagian luar runner $\beta_{1}$ dan ketebalan sudu yang dihitung menggunakan Persamaan 8 sebagai berikut.

$$
\begin{aligned}
s_{1} & =k \times D_{0} \\
& =0,0087 \times 54 \\
& =0,45 \mathrm{~cm}
\end{aligned}
$$

$\beta_{1}$ ditentukan sebesar $16^{0}$ sehingga jarak antar sudu didapatkan menggunakan Persamaan 9 sebagai berikut.

$$
\begin{aligned}
t \quad & =\frac{s_{1}}{\sin \beta_{1}} \\
& =\frac{0,45}{\sin \left(\operatorname { t a n } ^ { - 1 } \left(2 \times \tan 16^{0}\right.\right.} \\
& =0,9 \mathrm{~cm}
\end{aligned}
$$

4) Menghitung Lebar Sudu :

Lebar sudu dihitung menggunakan Persamaan 10 sebagai berikut.

$$
\begin{aligned}
a \quad & =0,17 \times D_{0} \\
& =0,17 \times 54 \\
& =9,2 \mathrm{~cm}
\end{aligned}
$$

5) Menghitung Jumlah Sudu :

Jumlah sudu dihitung menggunakan Persamaan 11 sebagai berikut.

$$
\begin{aligned}
n & =\frac{\pi \times D_{o}}{t} \\
& =\frac{3,14 \times 0,54 \mathrm{~m}}{0,09 \mathrm{~m}} \\
& =19 \mathrm{sudu}
\end{aligned}
$$

6) Menghitung Panjang Sudu :

Panjang sudu dihitung menggunakan Persamaan 12 sebagai berikut.

$$
\begin{aligned}
L & =\frac{Q \times N}{50 \times H_{n}} \\
& =\frac{1,32 \times 298}{50 \times 16} \\
& =0,5 \mathrm{~m}
\end{aligned}
$$

7) Menghitung Jari-Jari Kelengkungan Sudu :

$$
\text { Jari-jari kelengkungan sudu dihitung }
$$
menggunakan Persamaan 13.

$$
\begin{aligned}
r_{c} & =0,163 \times D_{o} \\
& =0,163 \times 54 \\
& =9 \mathrm{~cm}
\end{aligned}
$$

8) Menghitung Torsi Turbin :

Torsi turbin dihitung menggunakan Persamaan

14.

$$
\mathrm{T}=\frac{P_{t}}{2 \pi \frac{N}{60}}
$$

p-ISSN:1693 - 2951; e-ISSN: 2503-2372 


$$
\begin{aligned}
& =\frac{185.432,544}{6,28 \frac{298}{60}} \\
& =5962,46 \mathrm{Nm}
\end{aligned}
$$

\section{E. Desain Turbin Crossflow dengan CFD}

Karakteristik turbin crossflow yang akan didesain sebagai beikut.

Tabel 1. Spesifikasi turbin crossflow yang akan didesain

\begin{tabular}{|c|c|}
\hline \multicolumn{2}{|c|}{ Spesifikasi Turbin Crossflow } \\
\hline Daya Turbin & $185 \mathrm{~kW}$ \\
\hline Putaran Turbin & $298 \mathrm{rpm}$ \\
\hline Head Net & $16 \mathrm{~m}$ \\
\hline Debit Aliran & $1,32 \mathrm{~m}^{3} /$ detik \\
\hline Efisiensi Turbin & $89,5 \%$ \\
\hline Posisi Poros & Horizontal \\
\hline Sudut Serang & $16^{0}$ \\
\hline Torsi Turbin & $5962,46 \mathrm{Nm}$ \\
\hline
\end{tabular}

Karakteristik runner turbin crossflow yang akan di desain sebagai berikut.

Tabel 2. Karakteristik runner turbin crossflow yang akan di desain

\begin{tabular}{|l|c|}
\hline \multicolumn{2}{|c|}{ Karakteristik Runner Turbin CrossFlow } \\
\hline Diameter Luar Runner & $54 \mathrm{~cm}$ \\
\hline Diameter Dalam Runner & $36 \mathrm{~cm}$ \\
\hline Jumlah Sudu & $19 \mathrm{sudu}$ \\
\hline Jarak Antar Sudu & $0,9 \mathrm{~cm}$ \\
\hline Lebar Sudu & $9,2 \mathrm{~cm}$ \\
\hline Panjang Sudu & $50 \mathrm{~cm}$ \\
\hline Jari-Jari Kelengkungan Sudu & $9 \mathrm{~cm}$ \\
\hline
\end{tabular}

\section{F. Desain Runner}

Berdasarkan karakteristik runner yang telah ditetapkan maka dilakukan pendesainan runner menggunakan aplikasi komputer. Berikut hasil desain runner turbin crossflow.

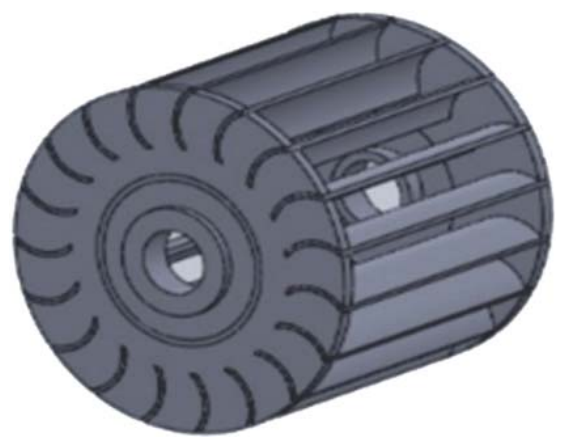

Gambar 7. Desain Runner

\section{G. Desain Sudu Turbin}

Berdasarkan parameter yang telah dihitung, maka desain sudu turbin sebagai berikut.

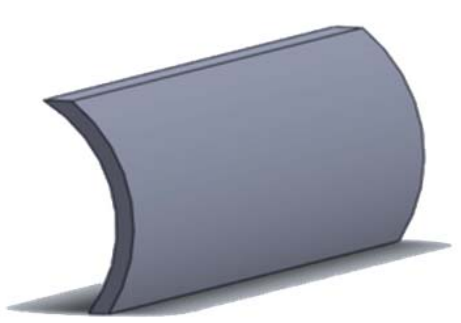

Gambar 8. Sudu Tampak Depan

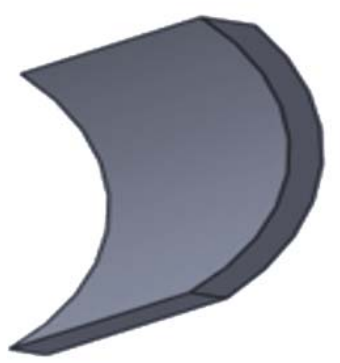

Gambar 9. Sudu Tampak Dalam

H. Desain Poros Turbin Crossflow

Berdasarkan parameter turbin crossflow maka desain poros turbin menggunakan aplikasi komputer sebagai berikut.

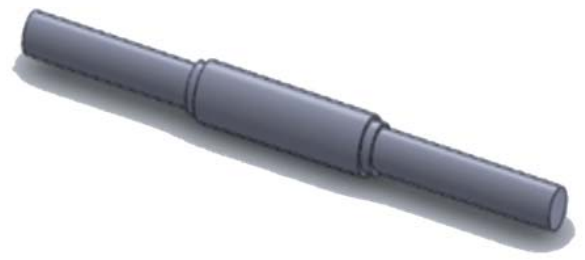

Gambar 10. Desain poros turbin crossflow

\section{Desain Turbin Crossflow}

Desain turbin crossflow berdasarkan perhitungan yang telah dilakukan adalah sebagai berikut.

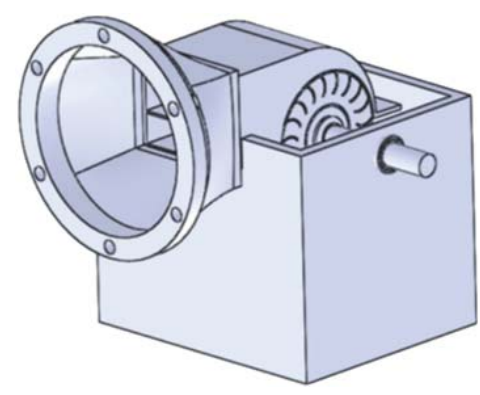

Gambar 11. Desain turbin crossflow

\section{J. Ketersediaan Turbin Air di Pasaran}

Berdasarkan hasil wawancara dengan salah satu pembuat turbin air yang ada di Indonesia, dapat disimpulkan dalam pemesanan turbin air tergantung pada head net dan debit aliran. Kemudian dari data tersebut pihak perusahaan 
akan mendesain turbin dengan spesifikasi yang disesuaikan dengan data head net dan debit aliran. Hal ini bertujuan untuk dapat memanfaatkan potensi yang ada pada sungai tersebut dengan maksimal. Sehingga untuk turbin crossflow yang telah didesain tidak perlu melakukan pencarian di pasaran untuk mendepatkan jenis turbin yang sesuai atau mendekati turbin yang telah didesain.

\section{K. Simulasi Turbin Crossflow}

Simulasi turbin crossflow menggunakan aplikasi CFD untuk menampilkan output torsi yang dihasilkan oleh turbin. Pada aplikasi CFD, simulasi turbin menggunakan 3 parameter yaitu kecepatan putaran turbin sebesar $298 \mathrm{rpm}$, kecepatan air masuk melalui connecting box sebesar 17,71 $\mathrm{m} / \mathrm{s}$, dan debit air yang masuk melalui connecting box sebesar $1,32 \mathrm{~m}^{3} / \mathrm{s}$. Connecting box merupakan komponen yang berfungsi untuk menghubungkan antara pipa pesat dengan turbin air. Selain itu, terdapat domain fluida yang merupakan area fluida itu mengalir atau di simulasikan. Hal ini dapat dilihat pada Gambar 12.

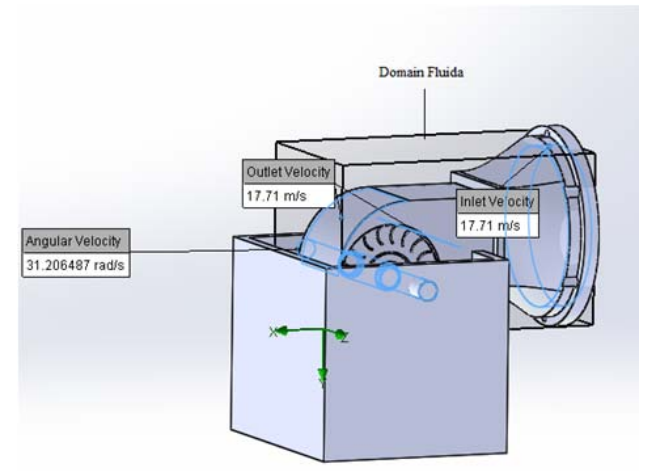

Gambar 12. Parameter simulasi turbin crossflow

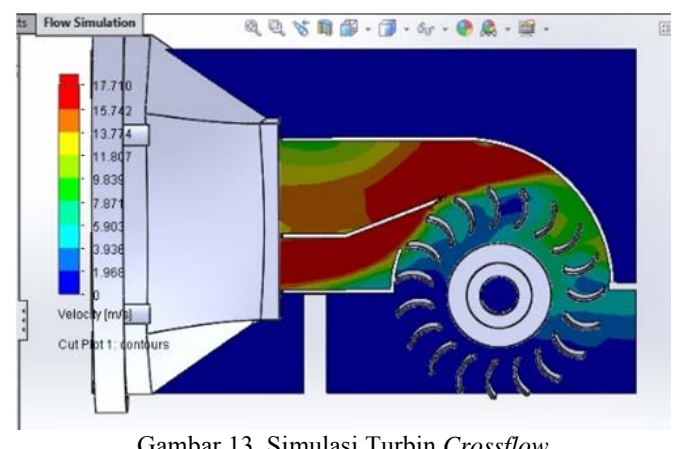

Gambar 13 menjelaskan bagaimana proses air masuk dari connecting box ke nozel dan di distribusikan ke sudu turbin. Dari Gambar 13 dapat diketahui pembagian tekanan air atas bagian atas dan bagian bawah tidak merata sehingga hasil keluaran turbin cenderung berfluktuasi. Hal ini dapat di lihat pada Gambar 14 yang menunjukkan hasil simulasi turbin crossflow.

Dewa Putu Ari Laksana : Redesain Turbin 175 KW Untuk ...

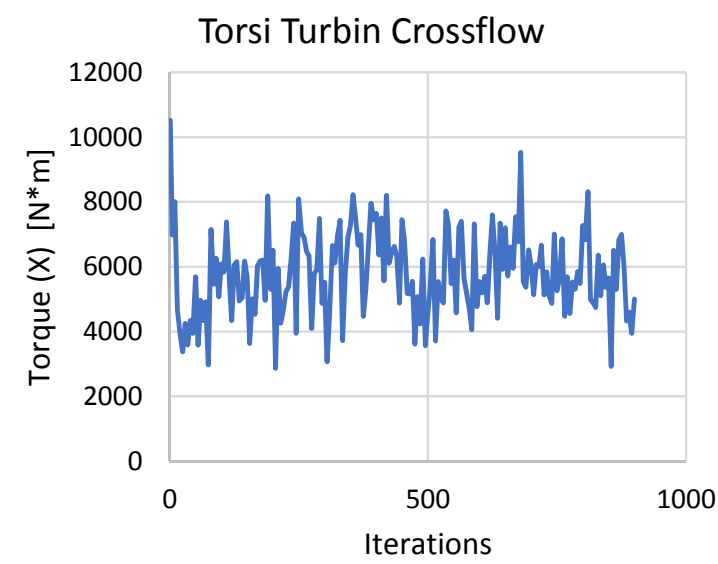

Gambar 14. Torsi keluaran turbin

Berdasarkan Gambar 14 dapat diketahui nilai keluaran torsi turbin terkecil yakni 2922,4 Nm, nilai keluaran torsi turbin tertinggi yakni 10518,152 Nm, dan rata-rata nilai keluran torsi turbin adalah $5622,1 \mathrm{Nm}$. Hal ini disebabkan oleh desain nosel yang sederhana. Nosel pada turbin crossflow membagi aliran menjadi dua bagian. Selain itu nosel juga mengubah arah dan kecepatan aliran air. Namun, untuk kecepatan dan arah aliran air tidak bisa dirubah karenakan posisi nosel yang permanen tidak bisa dirubah. Desain bentuk nosel ditunjukkan pada Gambar 15.

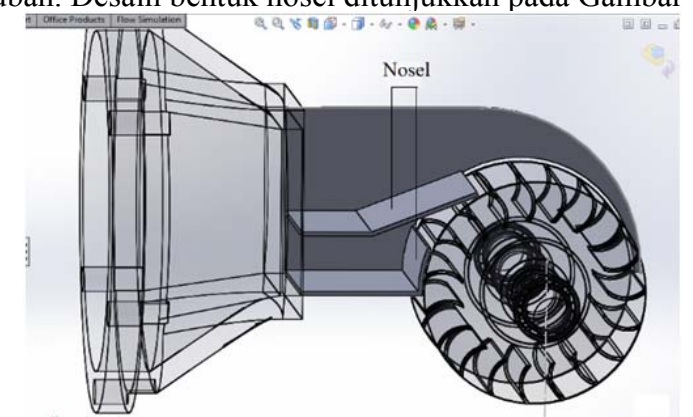

Gambar 15. Bentuk Nosel Turbin Air

Desain nosel yang kemungkinan besar mempengaruhi distribusi kecepatan dan tekanan air menjadi tidak merata. Akibatnya, kecepatan dan tekanan air yang diterima sudu-sudu turbin berpengaruh atau menyebabkan terjadinya fluktuasi pada torsi. Hal ini di dukung oleh penelitian Rendi tentang analisa distribusi dan aliran disekitar rotor savonius water turbine yang menyatakan bahwa tinggi rendahnya tekanan dan kecepatan aliran yang terjadi memberikan pengaruh terhadap putaran turbin sehingga memberikan dampak signifikan terhadap peforma turbin yang dihasilkan [20].

Dengan data hasil simulasi keluran torsi turbin crossflow maka daya keluaran turbin rata-rata dapat dihitung menggunakan Persamaan 14 sebagai berikut

$$
T=\frac{P_{t}}{2 \pi \frac{N}{60}}
$$

p-ISSN:1693 - 2951; e-ISSN: 2503-2372 


$$
P_{t} \quad=T \times 31,19
$$

Maka untuk daya keluaran turbin rata-rata adalah:

$$
\begin{aligned}
P_{t} & =5622,1 \mathrm{Nm} \times 31,19 \\
& =175353,299 \text { Watt atau } 175,353 \mathrm{~kW}
\end{aligned}
$$

\section{KESIMPULAN}

Berdasarkan perhitungan head net dan debit air yang dimanfaatkan, didapatkan jenis turbin yang paling sesuai dengan PLTMH adalah turbin crossflow dengan daya 185 kW. Hasil perancangan turbin crossflow memiliki spesifikasi teknis sebagai berikut: putaran turbin $298 \mathrm{rpm}$, torsi turbin 5962,46 Nm, diameter luar runner $54 \mathrm{~cm}$, memiliki 19 sudu, serta panjang runner $50 \mathrm{~cm}$.

Berdasarkan hasil simulasi dengan CFD didapatkan keluaran daya rata-rata turbin adalah $175,353 \mathrm{~kW}$. Hasil desain manual dan hasil simulasi CFD cukup mendekati yang menunjukkan bahwa potensi air dan head di lokasi PLTMH Mekar Sari sangat baik untuk menghasilkan daya PLTMH yang cukup besar.

\section{REFERENSI}

[1] I. N. S. Kumara, W. G. Ariastina, I. W. Sukerayasa and I. A. D. Giriantari, "On the potential and progress of renewable electricity generation in Bali," 2014 6th International Conference on Information Technology and Electrical Engineering (ICITEE), Yogyakarta, 2014, pp. 1-6, doi: 10.1109/ICITEED.2014.7007944.

[2]. Kumara, D. P. D. Suparyawan, W. G. Ariastina, W. Sukerayasa and I. A. D. Giriantari, "Microhydro powerplant for rural area in Bali to generate green and sustainable electricity," 2014 International Conference on Smart Green Technology in Electrical and Information Systems (ICSGTEIS), Kuta, 2014, pp. 113-117, doi: 10.1109/ICSGTEIS.2014.7038741.

[3]. Aribowo,A.A, Hermawan, Purnaweni, H. 2012. Partisipasi Masyarakat Dalam Pengelolahan PLTMH Di Desa Depok Kecamatan Lebak Barang Kabupaten Pekalongan.Jurnal EKOSAINS.,IV(2):30-40.

[4] SUPARYAWAN, DPD; KUMARA, INS; ARIASTINA, Wayan G. Studi Perencanaan Pembangkit Listrik Mikrohidro Di Desa Sambangan Kabupaten Buleleng Bali. Majalah Ilmiah Teknologi Elektro, [S.1.], v. 12 , n. 2, dec. 2013

[5]. Putu Diana Sari, I N S Kumara, THE DEVELOPMENT OF JATILUWIH MICRO-HYDRO POWER PLANTS TO SUPPORT TOURISM DESTINATIONS, 9-14, International Student Conference on Electrical and Computer Engineering, 2018

[6]. Gunawan, A., Oktafeni, A. \& Khabzali, W.2013. Pemantauan Pembangkit Listrik Tenaga Mikrohidro (PLTMH). Jurnal rekayasa elektrika. 10 (4): 20

[7]. Dwiyanto V. Analisis Pembangkit Listrik Tenaga Mikrohidro (PLTMH) Studi Kasus: Sungai Air Anak (Hulu Sungai Way Besai). Program S-1, Teknik Sipil, Universitas Lampung. 2016.

[8]. Parabelem T.D. Rompas “ Analisis Pembangkit Listrik Tenaga Mikrohidro (PLTMH) pada Daerah Aliran Sungai Ongkak Mongondow di desa Muntoi Kabupaten Bolaang Mongondow, “ Jurnal Penelitian Saintek, Vol. 16, Nomor 2, Oktober 2011 Universitas Negeri Manado.

[9] Dietzel, F.(1988). Turbin, pompa dan kompresor. Jakarta : Erlangga

[10]. Ismono H.A. 1999. Perencanaan Turbin Air Tipe Cross Flow untuk Pembangkit Listrik Tenaga Mikrohidro di Institut Teknologi Nasional Malang. Skripsi

[11]. C. A. Mocmoore, Fred Merryfield. TheBanki Water Turbine, Buletin Series No.25, 1949

[12]. Layman's Guidebooks. On How To Develop a Small Hydro Site. Journal Of Energy Saving. Vol. 1, No. 4, pp 67-70. 1998

[13] Alo Khomsah dan Efrita Arfah Zuliari ", Analisa Teori : Perfoma Turbin Cross Flow Sudu Bambu 5 Sebagai Penggerak Mula Generarotor Induksi 3 fasa , "Seminar Nasional Sains dan Teknologi Terapan III,2015, Institut Teknologi Adhi Tama Surabaya
[14]. Haimerl L. The Crosflow Turbine. Water Power, 1960, Volume 22, issue number 1, pp: 5-13

[15.] Zar Ni Tin Win, Htay Htay Wi, Myint Thein ," Design Contruction and Performance Test of Cross flow Turbine, " International Journal Mechanical and Production Engineering. Vol. 4, 12 Dec, 2016 ISSN 2320-2092

[16] C152.2014.Ossbergerturbine.http://www.ossberger.de/cms/en/hydro/the. Diakses: 2 Mei 2014

[17] I Wayan Budiarsana Saputra , Antonius Ibi Weking , Lie Jasa ," Rancang Bangun Pemodelan Pembangkit Listrik Tenaga Mikro Hidro (PLTMH) Menggunakan Kincir Overshot Wheel”. Jurnal MITE,Vol.16,No.02, Mei - Agustus 2017.

[18] Buyung,(2018). Analisis Perbandingan Daya Dan Torsi Pada Alat Pemotong Rumput Elektrik (Apre)(Jurnal). Politeknik Katolik Saint Paul Sorong

[19]. http://disdukcapil.bulelengkab.go.id/, diakses tanggal 28 Agustua 2020

[20] Rendi (2016). Analisa Distribusi Tekanan Dan Aliran Disekitar Rotor Savonius Water Turbine.Universitas Islam Kalimatan.Banjarmasin. 